\title{
Presence of epidermal growth factor receptor as an indicator of poor prognosis in patients with breast
}

\section{cancer}

\author{
JRC SAINSBURY,${ }^{*}$ AJ MALCOLM,† DR APPLETON,‡ JR FARNDON, ${ }^{*}$ AL HARRIS§ \\ From the Departments of *Surgery, §Oncology, †Pathology, and $¥$ Medical Statistics, University of Newcastle \\ upon Tyne
}

SUMMARY Epidermal growth factor receptors are present in some breast cancers in man, and there is an inverse relation to oestrogen receptor state. We assessed the presence of epidermal growth factor receptors as a single prognostic indicator in a series of breast tumours by comparing this with the Bloom and Richardson scores for these tumours. One hundred and eight ductal tumours were examined for epidermal growth factor receptors by radioligand binding. There was a significant $(p<0.01)$ correlation between the presence of the growth factor receptor and poor prognosis as assessed by the Bloom and Richardson score, suggesting that epidermal growth factor receptor state could be a useful prognostic marker. Epidermal growth factor receptor state was not significantly correlated with the lymph node state but showed a tendency to be associated with large tumours.

Epidermal growth factor receptors have been found in $35 \%$ of specimens of human breast cancer, and there is a negative association with oestrogen receptor state.' Epidermal growth factor receptors have been shown in other tumours including those of the lung, ${ }^{2}$ bladder, ${ }^{3}$ brain, ${ }^{4}$ ovary, and uterus. ${ }^{5}$

In culture epidermal growth factor is a mitogen for breast tissue ${ }^{6}$ that is both benign and malignant. ${ }^{78}$ It is an essential part of chemically defined serum free media for breast cancer cells. ${ }^{y}$ Functional epidermal growth factor receptors occur in the developing breast ${ }^{10}$ and have been shown in breast cancers both as cell lines and as biopsy specimens. ${ }^{11} 12$

Epidermal growth factor receptors closely resemble the oncogene $v$-erb- $\mathrm{B}^{13}$ and share with the oncogenic retroviruses the ability to cause phosphorylation of tyrosine residues of intracellular proteins (an unusual site of such activity). The confirmation of this similarity has led to the hypothesis that the signal induced by epidermal growth factor receptors might be responsible for uncontrolled growth of the cell. The erb-B product lacks the external binding site for epidermal growth factor, which may thus leave the receptor in a permanently activated state. This hypothesis of an

Accepted for publication 6 August 1985 overdrive mechanism remains to be proved.

The growth factors binding to the epidermal growth factor receptors may be produced locally by autocrine or paracrine mechanisms, and it has been suggested that the ability of a cell to both produce growth factors and express their receptors on the cell surface is a malignant phenotype.

There have been many attempts to correlate the histological appearance of tumour material, clinical data, and operative findings to ultimate outcome. The Bloom and Richardson scoring system ${ }^{14}$ based on three histological criteria is a well recognised discriminator. It can be refined into a more accurate system by incorporating details such as lymph node state (which is the best single prognostic factor at present) and size of tumour. ${ }^{15}$ Although oestrogen receptors are useful in predicting likely response to treatment and survival after first relapse,${ }^{16}$ they are not good at predicting time to relapse. Tumours positive for oestrogen receptors tend to relapse in bone and soft tissues and those negative for oestrogen receptors recur in the liver and brain. ${ }^{17}$ The oestrogen receptor state did not greatly increase the predictive power of either the Nottingham index ${ }^{15}$ or the recently reported analysis from Edinburgh. ${ }^{18}$

We investigated the relation between epidermal growth factor receptor state and prognostic factors such as the Bloom and Richardson grade, size of tumour, and lymph node state. When data of recurr- 
ence become available more direct evidence of a correlation with outcome will be sought.

\section{Material and methods}

One hundred and eight specimens of breast cancer were obtained fresh from surgery and processed immediately.' All the tumours had epidermal growth factor receptors assessed by a radioligand assay, and on 48 of these immunohistochemical analyses were subsequently performed. Briefly, a membrane preparation was obtained by differential centrifugation and aliquots incubated with iodinated epidermal growth factor $(0.6 \mathrm{nmol} / 1$, specific activity $2.96 \mathrm{MBq}(80 \mu \mathrm{Ci}) / \mu \mathrm{g})$ with or without known amounts $(0 \cdot 01-1000 \mathrm{ng} / \mathrm{ml})$ of unlabelled epidermal growth factor to displace the binding. From these data a Scatchard plot was derived. Positive tumours gave binding data with a mean dissociation constant of $1.7 \mathrm{nmol} / \mathrm{l}$ (range $0.7-2 \cdot 3$ ) with between 4 and 47 $\mathrm{fm} / \mathrm{mg}$ protein bound. Sixty two tumours were assessed by a two point assay in which duplicates of membrane preparations were incubated with iodinated epidermal growth factor either with or without $800 \mathrm{ng}$ unlabelled epidermal growth factor $/ \mathrm{ml}$. A displacement of greater than $75 \%$ was taken as positive.

Oestrogen receptors were measured on the tumour samples by a dextran coated charcoal method in accordance with the recommendations of the United Kingdom Quality Assurance scheme. Immunohistochemical analyses were also performed on 48 sections snap frozen at the time of collection. A monoclonal antibody against the external binding site of the epidermal growth factor receptors (gift of Dr MD Waterfield) was used and stained by the indirect peroxidase method. The working dilution of the primary antibody was $1 / 50$ and that of the secondary (Dako 261) 1/20. Sections of placenta (rich in epidermal growth factor receptors) were used as positive controls and preincubation of the antibody with purified receptor (prepared from A-431 cells, gift from Dr P Parker) before staining as negative adsorption controls. An irrelevant antibody of the same class (2a) was also used as a negative control. Sections were graded on $a+++,++,+, 0$ basis by

Table 1 Relation between epidermal growth factor receptor and oestrogen receptor

\begin{tabular}{llll}
\hline \multirow{2}{*}{$\begin{array}{l}\text { Epidermal growth } \\
\text { factor receptors }\end{array}$} & \multicolumn{2}{l}{ Oestrogen receptor } & Total \\
\cline { 2 - 3 } & Positive & Negative & \\
\hline Positive & 3 & 42 & 45 \\
Negative & 46 & 17 & 63 \\
\hline Total & 49 & 59 & 108 \\
\hline
\end{tabular}

$\chi^{2}=43.9$ with $1 \mathrm{df} ; \mathrm{p}=<0.001$.
Table 2 Relation between immunohistochemical and radioligand epidermal growth factor receptor assays

\begin{tabular}{lccc}
\hline $\begin{array}{l}\text { Radioligand } \\
\text { assay }\end{array}$ & \multicolumn{3}{l}{$\begin{array}{l}\text { Epidermal } \\
\text { receptor on }\end{array}$} \\
\cline { 2 - 4 } & Positive & Negative & Total \\
\hline $\begin{array}{l}\text { Epidermal } \\
\text { Positive } \\
\text { Negative }\end{array}$ & 21 & 5 & 26 \\
\hline Total & 2 & 20 & 22 \\
\hline
\end{tabular}

Specificity of immunohistochemistry $=91 \%$.

Sensitivity of immunohistochemistry $=81 \%$.

two observers and those given a +++ or ++ grade by either observer counted as positive. Routine histological examination was performed after fixation of the samples with formalin and impregnation with wax. Sections were stained with haematoxylin and eosin and assessed for degree of tubular formation (differentiation), hyperchromatic and mitotic figures, and nuclear pleomorphism. These were scored on a 1-3 basis and the scores totalled to give a 3-9 score. This scoring was performed with no knowledge of epidermal growth factor or oestrogen receptor state. Grade I comprised scores 3-5; grade II, 6-7; and grade III scores 8-9. Patients with tumours exhibiting a high score were likely to relapse and die earlier. ${ }^{14}$ This scoring system was used only for ductal carcinomas; lobular, mucinous, and other rare tumours (a further 11) were not graded or included in this analysis as the Bloom and Richardson scoring system does not allow for their assessment.

Estimates of elastosis and round cell infiltration were also scored on a 1-3 basis, and measurements of size of tumour and lymph node state (when available) were also recorded. The data were analysed by using a logistic transformation of proportions, both for single variable analysis and for a multivariate analysis to examine the effect of all the variables in combination. $^{19}$

\section{Results}

One hundred and eight tumours were included in

Table 3 Epidermal growth factor receptor and Bloom and Richardson score

\begin{tabular}{lrrrr}
\hline & \multicolumn{5}{c}{ Bloom and Richardson grade } \\
\cline { 2 - 6 } & $I$ & II & III & Total \\
\hline $\begin{array}{l}\text { Epidermal growth factor receptors: } \\
\text { Positive }\end{array}$ & 2 & 11 & 32 & 45 \\
$\begin{array}{l}\text { Negative } \\
\text { Total }\end{array}$ & 12 & 25 & 28 & 63 \\
Positive for epidermal growth & 12 & 36 & 60 & 108 \\
factor receptors (\%) & 17 & 31 & 53 & \\
\hline$\chi^{2}$ for logit linear trend in proportions $=$ & 8.64 with $1 \mathrm{df} ; \mathrm{p}=0.003$.
\end{tabular}


Table 4 Relation between size of tumour and epidermal growth factor receptor state

\begin{tabular}{|c|c|c|c|c|c|}
\hline & \multicolumn{5}{|c|}{ Size $(\mathrm{cm})$} \\
\hline & $<2$ & $2 \cdot 1-3 \cdot 5$ & $3 \cdot 6-5$ & $>5$ & Total \\
\hline \multicolumn{6}{|c|}{ Epidermal growth factor receptors: } \\
\hline Positive & 8 & 22 & 7 & 8 & 45 \\
\hline Negative & 21 & 28 & 9 & 5 & 63 \\
\hline Total & 29 & 50 & 16 & 13 & 108 \\
\hline \multicolumn{6}{|l|}{ Positive for epidermal } \\
\hline receptors (\%) & 28 & 44 & 44 & 62 & \\
\hline
\end{tabular}

$\chi^{2}$ for logit-linear trend in proportions $=3.97$ with $1 \mathrm{df} ; \mathrm{p}=0.046$.

this analysis. Forty five were positive for epidermal growth factor receptors by radioligand assay. The previously reported inverse relation between epidermal growth factor receptors and oestrogen receptors was again noted. Forty two of the $\mathbf{4 5}$ tumours positive for epidermal growth factor receptors were negative for oestrogen receptor state and 46 of 49 tumours positive for oestrogen receptor state were negative for epidermal growth factor receptors; three were positive for both and 17 doubly negative (Table 1).

There was good agreement between radioligand and immunohistochemical techniques. Of the 48 tumours assessed both ways, 41 showed agreement (Table 2). The specificity (defined as one minus the probability of a false positive) was $91 \%$ and the sensitivity (one minus the probability of a false negative) was $81 \%$. There was a significant association between tumours positive for epidermal growth factor receptors and high Bloom and Richardson scores. When assessed in the absence of other factors (Table 3$)$ this association was significant $(p<$ $0 \cdot 01$ ).

Table 4 shows that cancers positive for epidermal growth factor receptors tended to arise from a population of larger tumours; and Table 5 shows that spread to the lymph nodes was not conclusively related to epidermal growth factor receptor state, although this may have been due to the low number of tumours categorised for lymph node state. Elastosis and round cell infiltration were not significantly related to epidermal growth factor receptor state.

To examine the relation of epidermal growth fac-

Table 5 Relation between epidermal growth factor receptor state and lymph node state

\begin{tabular}{llll}
\hline \multicolumn{4}{c}{ Lymph node state } \\
\cline { 2 - 4 } & Affected & Unaffected & Not measured \\
\hline Epidermal growth factor receptors: & 9 & 15 \\
Positive & 21 & 15 & 34 \\
Negative & 14 & 15 & \\
\hline$\chi^{2}=2.05$ with 1 df. &
\end{tabular}

Table 6 Relation of epidermal growth factor receptor to size of tumour and Bloom and Richardson score

\begin{tabular}{|c|c|c|c|}
\hline Source & Deviance & $d f$ & $p$ \\
\hline $\begin{array}{l}\text { Log diameter: } \\
\text { without } B \text { and } R \text { grade } \\
\text { after fitting } B \text { and } R \\
\text { Bloom and Richardson: }\end{array}$ & $\begin{array}{l}3.51 \\
1.56\end{array}$ & $\begin{array}{l}1 \\
1\end{array}$ & $\begin{array}{l}\text { ns } \\
\text { ns }\end{array}$ \\
\hline $\begin{array}{l}\text { without fitting log diameter } \\
\text { after fitting log diameter } \\
\text { Residual }\end{array}$ & $\begin{array}{r}8 \cdot 64 \\
6 \cdot 70 \\
136 \cdot 5 \\
\end{array}$ & $\begin{array}{r}1 \\
1 \\
105 \\
\end{array}$ & $\begin{array}{l}0.001 \\
0.001\end{array}$ \\
\hline Total & $146 \cdot 71$ & 107 & \\
\hline
\end{tabular}

tor receptors with the various predictors for a poor prognosis a logistic discriminant analysis was performed. In this the actual tumour size (rather than the categorisation of Table -4) was used. Table 6 shows the contribution of each variable to the discriminant function. Only epidermal growth factor receptors were significantly related to the Bloom and Richardson score.

The follow up time was too short to analyse clinical relapse rates, but three of the four patients relapsing in under 15 months were positive for epidermal growth factor receptors.

\section{Discussion}

The Bloom and Richardson score is a good indicator of likely risk of recurrence ${ }^{14}$ and when combined with the presence of lymph node metastases and size of tumour (as in the Nottingham index ${ }^{15}$ ) is a good predictor of likely outcome. This index was initially derived retrospectively but has recently been shown to work in a prospective manner. ${ }^{20}$ The addition of staining intensity using a monoclonal antiepithelial antibody (NCRC 11) has been reported to increase further the accuracy of the index. ${ }^{21}$

Positivity for epidermal growth factor receptor seems to be an indicator of poor prognosis in breast cancer. This was suggested by the previous finding of an inverse relation between oestrogen receptor and epidermal growth factor receptors' ${ }^{1}$ tumours positive for epidermal growth factor receptors arose from tumours negative for oestrogen receptor state (therefore indicating bad prognosis). Why epidermal growth factor receptors should be present in this group of tumours is unclear. Other workers confirmed the presence of these receptors in specimens of breast cancer. ${ }^{22} 23$

Possibly, the expression of growth factors is akin to the secretion of $\alpha$ fetoprotein or carcinoembryonic antigen and signifies that dedifferentiation is 
occurring. Possibly, this group of tumours uses the epidermal growth factor receptors as the growth initiation signal either by overproduction of normal receptors or even by activation of the cellular oncogene. The second alternative is unlikely as c-erb has not been isolated from breast tumours and, also, as the predicted structure of the erb B product lacks the binding site for external growth factor.

This study showed a correlation between presence of epidermal growth factor receptors and high Bloom and Richardson grades that is independent of size of tumour, lymph node state, elastosis, and round cell infiltrate. One drawback of this study is that the epidermal growth factor receptors were compared with a predictive index and not an absolute such as death or recurrence. These data will emerge as the cohort of patients are followed up in the clinic. It will be interesting to see which combination of predictor variables will prove the best estimate of prognosis.

\section{References}

' Sainsbury JRC, Farndon JR, Shèrbet GV, Harris AL. Epidermal growth factor receptors and oestrogen receptors on human breast cancers. Lancet 1985 ; i: 364-6.

${ }^{2}$ Veale D, Marsh C, Ashcroft T, Harris AL. EGF receptors in human non-small lung cancer. $\mathrm{Br} J$ Cancer (in press).

${ }^{3}$ Neal DE, Marsh C, Sainsbury JRC, et al. Epidermal growth factor receptors in human bladder cancer: comparison of invasive and superficial tumours. Lancet 1985; i:366-8.

${ }^{4}$ Liebermann TA, Razon N, Bartel AD, et al. Expression of epidermal growth factor receptors in human brain tumours. Cancer Res 1984;44:753-60.

${ }^{5}$ Gullick W, Marsden JJ, Whittle N, et al. Expression of epidermal growth factor receptors on cervical, ovarian and vulval carcinomas. Cancer Res (in press).

- Taketani Y, Oka T. Biological action of epidermal growth factor and its functional receptors in normal mammary cells. Proc Natl Acad Sci USA 1983;80:2647-50.

7 Tonelli QJ, Sorof S. Epidermal growth factor requirement of cultured mammary gland. Nature 1980;285:250-2.

8 Imai Y, Leung CK, Frieson HG, Shiu RPC. Epidermal growth factor receptors and effect of epidermal growth factor on growth of human breast cancer cells in long term tissue culture. Cancer Res 1982; 42:4394-8.

' Barnes D, Sato G. Growth of cells in hormonally defined media. Anal Biochem 1980;102:255-70.

${ }^{10}$ Adamson ED, Deller MJ, Warshaw JB. Functional EGF receptors are present on mouse embryo tissues. Nature 1981;291:656-9.

" Osborne CK, Hamilton B, Nover M. Receptor binding and processing of epidermal growth factor by human breast cancer cells. J Clin Endocrinol Metab 1982;55:86-93.

${ }^{12}$ Fitzpatrick SL, LaChance MP, Schultz GS. Characterization of epidermal growth factor receptor and action on human breast cancer cells in culture. Cancer Res 1984;44:3442-7.

${ }^{13}$ Downward J, Yarden Y, Mayes E, et al. Close similarity of epidermal growth factor receptor and v-erb-B oncogene protein sequences. Nature 1984;307:521-7.

14 Bloom HJG, Richardson WW. Histological grading of breast cancer. Br J Cancer 1957;11:359-77.

is Haybittle JL, Blamey RW, Elston CW, et al. A prognostic index in primary breast cancer. Br J Cancer 1982;45:361-6.

${ }^{16}$ Howell A, Barnes DM, Harland RNL, et al. Steroid hormone receptors and survival after first relapse in breast cancer. Lancet 1984; i:588-93.

${ }^{17}$ Stewart JF, King RJB, Sexton SA, et al. Oestrogen receptors, sites of metastatic disease and survival in recurrent breast cancer. European Journal of Cancer 1981;17:449-53.

${ }^{18}$ Nixon SJ, Steele RJC, Hawkins AR, McGregor J, Forrest APM. Prediction of recurrence after mastectomy for operable breast cancer. Br J Surg 1985; 1:7-9.

${ }^{19}$ Baker RJ, Nelder JA. The GLIM system (release 3) manual. Numerical algorithms group for the Royal Statistical Society. Oxford, 1978.

${ }^{20}$ Blamey RW, Hinton CP, Campbell FC, Haybittle JL, Elston CW. A prognostic indicator in breast cancer-tested and confirmed. Breast Cancer Res Treat 1984;4:335.

${ }^{21}$ Hinton CP, Ellis I, Robins RW, Elston CW, Blamey RW. The prognostic-significance of monoclonal-antibody staining of human breast cancer. Breast Cancer Res Treat 1984;4:337.

${ }^{22}$ Fitzpatrick SL, Brightwell J, Wittliff JL, Barrows GH, Schultz GS. Epidermal growth factor binding by breast tumour biopsies and relationship to estrogen receptor and progestin receptor levels. Cancer Res 1984;44:3448-53.

${ }^{23}$ Perez R, Pascual M, Macias A, Lage A. Epidermal growth factor receptors in human breast cancer. Breast Cancer Rest Treat 1984;4:189-93.

Requests for reprints to: Mr JRC Sainsbury, Department of Surgery, New Medical School, University of Newcastle upon Tyne, Framlington Place, Newcastle upon Tyne, NE2 4HH, England. 